\title{
Greek dance and everyday nationalism in
}

\author{
contemporary Greece
}

\author{
Sofia Kalogeropoulou
}

The University of Otago

\begin{abstract}
In this article I explore how dance as an everyday lived experience during community events contributes to constructing national identities. As a researcher living in New Zealand where issues of hybridity and fluidity of identities in relation to dance are currently a strong focus for discussion, I was inspired to examine dance in my homeland, Greece. In a combination of ethnography and autobiography I examine dance as an embodied practice that physically and culturally manifests the possession of a distinct national identity that can also be used as a means of differentiation. I also draw on the concept of banal nationalism by Michael Billig (1995), which looks at the mundane use of national symbols and its consequences. I argue that while folk dance acts as a uniting device amongst members of national communities, its practice of everyday nationalism can also be transformed into a political ritual that accentuates differences and projects chauvinism and extreme nationalism with a potential for conflict.
\end{abstract}

\section{INTRODUCTION}

A few years ago when I was still living in Greece I was invited to my cousin's farewell party before he went to do his national service. This is a significant rite of passage for a Greek male marking his transition from childhood to manhood and also fulfilling his obligations towards his country and the state. This dance event celebrates the freedom of the civilian life and marks the beginning of a twelve-month period of military training in the Greek army. The party was taking place in the backyard of his home where tables had been joined together, forming a long line to accommodate the members of the immediate family, friends and relatives. At everyone's arrival we filled our glasses with wine and after a toast to my cousin we feasted on Greek salad, roasted lamb and spinach pie. At some stage Giorgos (my cousin's friend) pressed play on the CD player and turned up the volume while the rest of us pulled the chairs and tables further back to create a dancing space. Giorgos led the first dance and the rest of us followed. At the end of the dance one of the other guests filled up a glass 
of wine and placed it on the ground in the middle of the dancing space. My cousin rolled up his sleeves, raised his arms and, clicking his fingers, stood by the glass. He dragged one foot close to the other and rocked from side to side. He staggered from left to right and gradually started to spin around the central axis of his body and around the glass. His arms were still stretched out to the side and his chest projected towards the ground. Most of us had formed a circle around him clapping, slapping the ground and calling out "ala" and "opa”. This was the beginning of a long night of dancing.

This event is one example of where, how and why Greek people dance. With a strong interrelationship with music and song, dance is performed alongside social activities such as eating and drinking to mark a variety of public and private occasions in Greek society. Greek dance is part of global celebrations such as New Year, national festivities or localised religious feasts (panigyri) in honour of a saint. It marks formal and informal rites of passage such as weddings, baptisms or the departure of a man into the national service, as the above example illustrated. Greek dance is not confined to a specific place or a particular time; it can spring-up spontaneously at picnics or in people's backyards after dinner for the sake of digestion (Cowan, 1990; Manos, 2002, 2003; Raftis, 1987). Hence, while the context, temporality and spatiality of the dance events might vary, they constitute an integral part of everyday life in Greece.

In this article I explore the role of folk dance in Greece in enhancing national consciousness and contributing to nation-building in everyday events, social gatherings, religious festivities and rites of passage. I look at Greek dance in its "first existence" where it is learned and practised in its natural environment, i.e. community settings, and is transmitted from one generation to the next by the process of enculturation, ${ }^{\text {i }}$ as opposed to "folk dance in its second existence" which includes the theatricalised performances of amateur and professional folk dance ensembles (Hoerburger, 1968; Kealiinohomokou, 1972; Shay, 1999). In this way, I examine Greek folk dance as a form of everyday nationalism exercised by the masses (the people) and assess its contribution to the reproduction of culture that cultivates a distinct national character. I argue that while dance fosters a positive reinforcement of national identity-a form of benign nationalism-it can also become the medium of exclusion and differentiation in relation to other national or ethnic groups. I draw on the concept of 'banal nationalism' introduced by sociologist Michael Billig (1995), 
who views national identity as an everyday lived experience and nationalism as a notion that it is practised and reproduced through life's everyday routine and banality. This framework will be used to analyse my first-hand accounts as a Greek and the interviews from fieldwork conducted in Greece in 2011. The voices of the small group of participants enriched the study and helped to illuminate the role of dance in shaping national identity.

The article is structured as follows: in the first section, I introduce myself and my positionality as a researcher. In the second section I examine the role of the dance events and the dance itself in the Greek community's everyday formal and informal functions. Through this analysis, I consider how folk dance, as a cultural signifier of social relations and also as a pleasurable activity, constitutes a form of banal nationalism in defining Greek identity. In the third part, I illustrate that the idea of 'Greek dance' is created through distinguishing between 'us' and 'them'-in other words, through 'othering'. I argue that differences between Greek dances and similar dances in the Balkans region, or even those within Greece itself, are exaggerated to confirm the Greek identity. I conclude by engaging in a critical reflection on how my research has shaped my own perception of dance and identity as a Greek in the diaspora and as a dance researcher.

\section{METHODOLOGY}

In this study I employed an autoethnographic methodology-a combination of autobiography and ethnography-in which the culture of one's own group is contextualised and the researcher engages in a critical reflection on their personal experiences (Madison, 2012). I grew up in Lamia, a small town in mainland Greece, where I learned Greek dancing as a child and continued to practise it as an adult during the various community social functions. Thus, I draw on my first-hand experiences and memories as a Greek. However, for the last seventeen years I have been living abroad, first in London and now in New Zealand where I teach, study and research dance. Living abroad has prevented an immediate interaction with the Greek community and the social norms and ideas that shape the society of my homeland. Consequently, it has created a reflective space for me regarding the constructed self and Greek culture. Being part of a multicultural society has offered me the opportunity to be in a constant dialogue with 'other' identities and cultures. I have also experienced being labelled the 'other', i.e. as 'the Greek', amongst New Zealanders; hence, I have become 
more compassionate towards the 'other'. ii All of these experiences, in conjunction with studying and researching dance, have contributed to new ways of seeing, valuing and perceiving various ways of belonging and questioning the role of dance as a medium of belonging. As Babcock (cited in Foley, 2002, p. 473) claims:

Directing one's gaze at one's own experience makes it possible to regard oneself as 'other'. Through constant mirroring of the self, one eventually becomes reflexive about the situated, socially constructed nature of the self, and by extension, the other. In this formulation, the self is a multiple, constructed self that is always becoming and never quite fixed, and the ethnographic productions of such a self and the cultural other are always historically and culturally contingent.

To support my autoethnographic research, I also conducted interviews in Lamia in 2011, aiming to understand how Greek people perceive their identity through folk dance and whether it is a significant element in affirming national consciousness in Greece today. My participants were members of the wider Greek community, friends and relatives of mixed gender and some from different regions within Greece. They were informed of the purpose of the interviews and were given a consent form which was approved by the University of Otago Ethics Committee, along with a sample list of questions that formed the basis of the discussion. The informants generally expressed a preference to be interviewed as a group rather than individually, as they found this prospect unnerving. So I conducted the interviews in an informal manner (using an open-questioning technique), ${ }^{\text {iii }}$ usually over a meal accompanied by Greek wine and food. This, on the one hand, proved to be fruitful because it created a lively discussion around nationhood and dance and enabled the participants to respond to each other's comments. On the other hand, at times the conversation drifted onto the financial crisis, which is of great concern in Greece at present, and it was hard to redirect the group discussion back to my topic.

Studying one's own society and culture entails certain privileges and poses epistemological issues. My upbringing in Greece meant that there were no cultural and linguistic barriers, and therefore a greater understanding could be achieved than anywhere else (Strathern, 1987). Most importantly, I had experienced and embodied dance physically and culturally in a similar manner to my interviewees and I was aware of the socio-political and historical situations 
that had shaped my participants' views. Therefore, I could better understand their views and opinions. At the same time, as a Greek of the diaspora I was drawing on my personal experiences inside and outside Greece, which had influenced and re-shaped my views in relation to dance, culture and identity representations. This created a dialogic interplay between an insider/outsider and a self/other researcher that allowed for a critical review of dance as a representational identity.

Stella Mascarenhas-Keyes (1987) argues that a researcher who studies their own culture should aim to create and maintain a distance between self and the community under study. This means that the researcher will have to "disengage the personal from the ethnographic" in order to provide a value-free analysis (Manos, 2002, p. 26). Such an approach, however, undermines the fact that fieldwork relies on the interaction of the self/researcher with the participants (Okely, 1992). Furthermore, it rests on the claim that there can be a critical judgement of an objective reality and presupposes the existence of a single truth (Manos, 2002). So, I challenge the notion of a value-neutral fieldwork and join Soyini Madison (2012) in claiming that "doing fieldwork is a personal experience. Our intuitions, senses and emotions are powerfully woven into and inseparable from the process" (p. 9). Whether the researcher is a cultural 'outsider' or 'insider', they enter the field with certain dispositions and views about the community under study which have been formed by their upbringing, personal experiences and education. Therefore, I adopt the concept of positionality or reflexive ethnography where, as researchers, we are morally and ethically accountable for our own positions and criticisms (Madison, 2012). This framework allows me to present my views as a Greek but also to be prepared to shift identifications and provide a critical stance.

\section{DANCING GREEKNESS IN EVERYDAY LIFE}

\section{The dance events}

Dance events in Greece are a means of socialising and entertainment; therefore, they can be seen as an escape from everyday life activities. As Jane Cowan (1990) states, dance events are "idealised" by the Greeks as occasions of "pleasure, conviviality and release” (p. 5). As previously mentioned, Greek dance events incorporate dance, music, song, food and drink, all of which individually and collectively promote the idea of an ideal lifestyle. This lifestyle is 
conceptualised by the Greeks as a sign of kalozoia (good life)-a life that boosts and promotes both their physical and psychological well-being (Doulias, Kosmidou, Paulogiannis, \& Patsiaouras, 2005; Mavrovouniotis, Argiriadou, \& Papaioannou, 2010). Dance events offer Greek people an opportunity to satisfy their physical desires through pleasurable activities such as dancing (as a form of exercise), eating and drinking as well as fulfilling their psychological need to experience a range of emotional states (Devettere, 2002). This physical and emotional self-gratification also cultivates the idea of a prosperous nation where people live well and are doing well. For example, during a name-day event (the celebration of the name of the saint that people are named after), I vividly remember my neighbour verbally contextualising the abstract notion of it in national terms by stretching his arms and calling out that 'life is great in Greece'. Thus, dance events, as sources of kalozoia, mark a distinctive lifestyle that underpins the Greek national identity.

Dance events in Greece can be seen as ritualistic practices that symbolically bond the cultural collectivity through the various ordinary activities previously mentioned. For example, Cowan (cited in Panopoulou, 2008) makes a valuable observation in regards to the role of the table in Greek community. She claims that the table is not "simply a material reproduction of an already formed group, but the place where the group actively forms itself" (p. 453). Hence, the deployment of food and drink, as in the case of my cousin's party, surpass their banal function and act as a metaphor for collective unity (Yiakoumaki, 2006). Dance events are also defined by protocols and unwritten codes that communicate meanings and ideas to the members of that particular cultural group (Sklar, 2001). For example, when my cousin's friend placed the glass on the ground, without any verbal communication he indicated that it was time to dance. His gesture also signalled that the dance would be performed by my cousin. So, dance events encapsulate cultural codes which act as signs that convey messages and ideas that can be understood by the cultural insiders (Hanna, 1979). This means that people possess a collective cultural knowledge and drawing on that common stock of knowledge "enables them to recognise a set of movements" and attribute meaning to them (Ward, 1997, p. 13). This simultaneously draws the boundaries around this particular group that understands the concepts embodied in the particular action and creates 'cultural outsiders' who, in order to understand those unwritten codes, will have to seek verbal explanations. 
However, occasionally there is no rational explanation behind unwritten cultural protocols. For instance, when I asked Roula about the glass, she raised her shoulders and replied: "Etsi to'houme emeis; einai synethia" ("We have it this way; it's a habit"). Etymologically the word synethia (habit) in Greek means an action that is performed automatically or mechanically after a regular and repetitive practice. The word synethia is also synonymous with custom, a habitual cultural pattern that my cousin's friend reproduced. However, Roula's statement that emeis (we) possess the custom, shows that it is not only my cousin's friend that performs and reproduces the custom but the broader community, the national community. Roula sees herself as part of an imagined community (Anderson, 2006) that engages in the same Greek dance rituals and adheres to the same Greek customs and protocols. This reflects Billig's (1995) idea that the nation is conceptualised in the political rhetoric through the linguistic convention of deixis-the use of small words such as 'we' and 'us'. So while deixis is employed by politicians to remind people that they are part of a national community, so do the people remind themselves-by employing the word 'we' in their dance rituals-that they are part of a broader national community (see also Wodak, de Cellia, Reisigl, \& Liebhart, 2009).

\section{The dance itself}

So far I have examined Greek dance events as mediums that bind the Greek community together. I will look now at the way that the dances themselves infuse a sense of Greekness. Folk dance has the ability to achieve group unity, bringing different members of the family and the community together through its form and structure. Characterised by circular formations and simplicity in their steps (often at a walking pace), folk dances allow for the participation of every generation, young and old (Wingrave \& Harrold, 1984). So parents can dance with their children and grandparents can dance with their grandchildren. In this way, dance bridges the gap between different generations and provides them with a common cultural and physical activity that they can participate in and enjoy together (Zikos, 1993). The fact that children participate in the same dances as their parents and their parents' parents illustrates that they belong to the same cultural family and share a common heritage and dance tradition (Dimaras, 1972; Raftis, 1987).

The family setting provides the perfect vehicle for the cultural initiation of younger generations to Greek dance traditions. It is common to see children 
running around, playing and joining the dances at the Greek events. They usually constitute the tail of the dancing circle, mainly walking around following the adults and often getting stepped on when some of the steps travel backwards or clockwise. Regardless, the repetitive motif of the dance steps as well as the children's regular participation in dance events results in them embodying the steps, the idiosyncrasies of movement, the rhythm of the dance (Barboussi \& Vidali, 2009; Riak, 2011). Children also learn by observing the dance. For example, one of Panopoulou's (2008) informants stated that by the time he joined the dance he already knew how to dance. In this way, children capture the mood, the appropriate facial expressions, the vocal exclamations such as "ala!" and "opa!" that accompany the dance. So, when learning takes place in the natural cultural environment and children are actively involved in the process of the dance, they unconsciously absorb Greekness. Greekness then is embedded in the body.

Looking at the variety of Greek dances and the order in which they are performed at each occasion, it is apparent that they reflect the historical development of the Greek nation and the way in which its evolution has been reflected in dance (Patsidou \& Mavromati, 2004). For example, the majority of celebrations start with the rural folk dances of syrtos, kalamatiano and tsamiko and continue with the urban dances of zeimbekiko and tsifteteli. The first dances are intimately tied to the rural Greek landscape and represent the authentic roots of the nation and its people (Holst-Warhaft, 1998). These dances are also associated with the struggles for liberation from Ottoman rule and the establishment of an independent state in the 19th century (Shay, 2008). Evidently, the Greeks of the 21st century have continued to identify themselves with the rhythms of the rural folk dances and the national values they encase. Similarly, the urban dances that have been incorporated in the national dance repertoire reflect the effects of urbanisation, individualism and the life of internal refugees to the city (Loutzaki, 2001). Equally, urban dances are historically laden as they mark a tragic moment in the new nation's profile. The defeat of the Greek forces in the Greco-Turkish war of 1919-1922 resulted in the exchange of Christian and Muslim populations between Greece and Turkey (Zografou, 2007). The negotiation of identity in a new environment for both internal and external refugees is depicted in those dances (zeimbekiko and tsifteteli) and their performance in contemporary life acts as a reminder of national history (Holst-Warhaft, 1998). Hence, the performance of both urban 
and rural dances in the same event threads a national past through the present and signals a continuation in the future. In this way, Greek history is danced at every event.

The performance of dances which encapsulate the history and the cultural heritage of the nation can perhaps explain the sense of pride they infuse in the people who dance them. In particular, Amalia's response was distinct: "I can't find the right words for it but my whole being is dancing and yes, I do feel proud when I perform our dances ... they are part of our heritage" (personal communication, June, 2011). Drawing on Amalia's comment, it is obvious that her sense of pride and self-esteem derives from the thought of possessing a dance heritage that she shares with the rest of the national community and which is specific to the Greek nation (Callos, 2012). According to Raymond Devettere (2002), an analyst of Aristotelian ethics, pride is also synonymous with honour, and is a feeling that "confers prestige and privilege, and the honoured person receives the respect and admiration of others" (p. 75). Hence, when Greek people dance, they express appreciation of and respect for their ancestors, who left them a rich dance tradition of folk dances (Doulias et al., 2005). At the same time, this creates a sense of privilege and prestige for being the recipients of such a unique dance tradition.

Folk dance generates a sense of pride that is consciously associated with the nation and the nation's ancestry, but, as Christos, another of my interviewees, pointed out, dance can also physically manifest the feeling of pride. "When someone dances," he said, "you can see; his back is straight and his chest puffed up full of pride" (personal communication, July 2011). So Greek people not only experience the feeling of pride but can also project this emotional state to others through the dancing body. They can non-verbally articulate what it is to be Greek, feel Greek and move like a Greek and communicate it clearly to observers (Loutzaki, 2001; Papakostas, Prantsidis, \& Polatou, 2006). One of my interviewees, James, who is English but has also lived in Greece, remarked that "Greeks have a noticeable sense of possessing a particular culture and take pleasure in celebrating that culture through dance in a way that some other nations do not" (personal communication, March 2012).

\section{Dance and song}

Folk dance is effective in communicating Greekness partly because it is interlinked with song. Written and sung in the native language that everyone can 
understand, the lyrics of the songs become the narrative of the nation and its people. They convey social and religious values and ideas that people share and also learn to share (Herzfeld, 1982). For instance, the lyrics of the following song allude to the ephemeral nature of the physical body, but at the same time make a statement about the religious spirit (in Greece, according to Orthodoxy, deceased bodies are buried and are not cremated): 'Touti gi pou tin patoume oloi messa the' na boume' ('We are all going to be buried in this earth that we stamp on'). While the song acts as an audio stimulus of those ideas, the dancing body internalises and embodies those concepts. The use of the word 'we' in the song addresses the nation and its people, while the dance brings the 'we'-the people-physically closer as they are linked together hand-by-hand or shoulderto-shoulder. Although the words of the song sound macabre, it is actually a happy tune danced as syrtos. My friends and I used to compete in stamping our feet on the ground while dancing and through our light-hearted competition the words of the song were enacted through our bodies. Hence, the dance and song link values and religious beliefs and also connect with the Greek land and its dancing people. The repetitive motif of the verses reinforces those concepts and, in combination with the repetition of the dancing steps, results in their embodiment. Nevertheless, as Athan Karras (2012) states, “Finding a kinaesthetic response while doing the syrtos we do not articulate our feelings verbally. The vibrations speak louder than words" (p. 38). This showcases the strength of dance to communicate ideas in a unique way that has the potential to go beyond many other audio-visual media of persuasion (Hanna, 1979).

The above discussion about dance events has shown that they create an environment that fosters a sense of Greekness that is 'flagged' by dance protocols, Greek food, Greek music, Greek songs. In those events the participants continuously engage in viewing, tasting, hearing and dancing the nation. All these elements reproduce a nation in a "banally mundane way" (Billig, 1995, p. 6) and enhance a strong sense of Greek nationhood while contributing to its continuous re-instatement. Dancing, in particular, shapes a distinctive national body that encapsulates and projects the Greek national identity. So, dances, like other "bodily performances, are instrumental in constructing a bodily mnemonic habitus, a sensuous reception of national 'truths"” (Hamilakis, 2003, p. 61). In other words, national identity is embedded in dance as part of the norm or the habitual and the spontaneous way that the individual acts. 
This is in line with Billig's theory that the nation is continuously 'flagged' by national symbols such as flags, stamps, national anthems and news; images and audio stimuli that act as reminders of national identity. Further, Billig (1995) argues that the mundane use of national symbols along with an exclusive political rhetoric results in an unconscious absorption of nationalism with malign consequences. This is especially prominent in times of national instability when national consciousness can be evoked and mobilised by the state in order to meet political needs and aspirations. I argue that the practice of folk dance in everyday life is equally important to the study of nationalist discourse as it contributes to the embodiment of national identity that, under certain circumstances, can fuel national sentiments and project extreme nationalism. However, my analysis deviates from Billig's (1995) concept of a nationalism led by the elite (politicians, media). It rather explores the cultivation of national feelings through folk dance amongst the population, taking into accounts notions of collective human agency.

\section{MARKING DIFFERENCE THROUGH GREEK DANCE}

In the previous section I presented folk dance as an embodied discourse of Greekness and a positive affirmation of national identity. The practice of folk dance in everyday life binds individuals together into a homogenous cultural collectivity and shapes a common consciousness of belonging to the same national community. Nevertheless, while folk dance becomes a point of reference of the Greek identity, it also acts as a means of differentiation from other identities. In other words, folk dance defines 'us' and also differentiates 'us' from 'them', i.e. those who are not part of the national community, and the sense of identity itself may be created through this 'othering'. By creating and including the national 'us' while simultaneously differentiating and excluding 'them', the concept of possessing a distinct national dance identity may form an exclusive ideology. In particular, folk dance becomes problematic when it creates a difference that is laden with essentialist and primordialist ideas about the nation and a sense of superiority in relation to the 'other'. Under certain political conditions, these exclusive ideologies can evoke strong national feelings and lay the foundation for an extreme form of nationalism with potential for conflict.

\section{Can an English person dance a Greek dance?}


As I previously illustrated, Greek dance events and the dances themselves are inclusive to all community members but they can also become a means of exclusion. An example of this is the wedding ceremony, a rite of passage that takes place in the church and requires both people to be 'Greek'. 'Greek', in this case, means being Greek Christian Orthodox because the church prohibits marriage between a Christian Orthodox and non-Christian Orthodox. ${ }^{\text {iv }}$ For instance, my husband Jim, who is English, had to be baptised Greek Orthodox in order to get married in church. Central to the ritual is a dance called Isaiiah horeve (Isaiah Dance), in which the couple hold hands and circle around the altar along with the best man and the priest while the congregation throws rice and almonds at them (as a symbol of prosperity and happiness; Allenby-Jaffe, 2006). So in the ceremony, dance symbolically unites the couple and at the same time brings together customs and religion. The state is also complicit in this demarcating of a separate Greek national identity. Until 1982, only religious marriages were recognised as legal by the Greek state (civil marriage was introduced as an alternative but the majority of the population still marries in church; Mavrogordatos, 2003). Thus, both the church and the state subscribed to the view that the wedding dance could only be performed by two people who shared a common Greek national identity and religious dogma-a concept that reflects Van de Berghe's (2005) primordialist idea that nations are "super families" that are "knit together by horizontal ties of marriage" (p. 274). In other words, a wedding ceremony in Greece can be seen as enhancing primordial ties between people and creating a conception about a Greek wedding that it is performed only by Greek people.

Similar processes of exclusion through dance arise at the wedding reception, to trapezi (the table), which follows the ceremonial ritual. It is customary that the first dance at the reception is performed by the bride followed by the groom, the best man and the immediate families (Glauser, 2005; Raftis, 1987). At my wedding reception in Greece in 2009, soon after I led the kalamatiano, Jim took his place at the beginning of the circle to lead the tsamiko dance, as is traditional for the groom. At that moment I caught a glimpse of Stella, one of my relatives, folding her arms in front of her chest and sarcastically remarking, 'O gambros sta tria!' ('The groom will dance a 3/4!'). It was obvious from her body language and the tone of her voice that she could not believe that Jim was going to dance tsamiko since, as already discussed, tsamiko 
is intimately tied to rural Greek landscape and encapsulates the essence of Greekness.

Stella's comment raises an important question: Can somebody who is not Greek dance a Greek dance? Firstly, it was assumed that Jim could not dance tsamiko properly because he had not gone through the process of enculturation that I discussed in the previous section. Secondly, it is obvious that Stella's remark also had primordialist connotations that perceive folk dance as tied to genetic descent, a conception that also conforms with Dina's view that Greek people have Greek dance “in their blood” (personal communication, June 2011). In other words, Greek folk dance is conceptualised as an inherited national quality that is exclusive to Greek people, defined both genetically and culturally. People (including immigrants) who are not of Greek descent and brought up in Greek culture might be able to mimic the dance but would not experience the same sense of pride in the common heritage as a Greek would. Thus, non-Greeks cannot embody the dance and the values associated with it. So the idea of Greek dance for Greek people excludes from the nation those who cannot embody the dance. Consequently, this contributes to making Greek national identity exclusive and may prevent immigrants from being accepted into the nation. Indeed, studies have shown that in general, Greeks have a more exclusive conception of the nation than some other countries (Janmaat, 2006). ${ }^{v}$ However, immigrants from the Greek diaspora-such as the Pontiacs from the Black Sea-are more likely to be accepted as being capable of embodying the dance because they are seen as part of the imagined Greek community.

\section{Minor differences, major implications}

Processes of exclusion also occur not just through ideas of who can dance Greek dances, but also in relation to ideas of what constitutes a Greek dance and how Greek dance is different to other national dances. There are major stylistic differences between Greek folk dances and those of northern Europe, even though they may perform similar functions (Allenby-Jaffe, 2006). These major differences between dances can be positive in that they may "boost individualization and promote cultural tolerance" because they provide a "selfreferential system that enables the actors to reflexively engage with the difference of the Other" (Zografou \& Pipyrou, 2011, pp. 423-424). Dance provides a psychological boost and a sense of pride as a symbol of cultural achievement that is unique to the particular cultural group (Tvrtko, 1996). 
However, there are significant similarities in choreological structure and form among dances in the Balkans, especially as they maintain the circular formation (Allenby-Jaffé, 2006; Rakočević, 2005). In this context, Greeks may exaggerate the differences and place emphasis on fairly minor features of differentiation in order to retain their unique sense of identity. This has been called the "narcissism of minor differences" by which people emphasise the differences between their culture and the culture of neighbouring groups, which they often denigrate (Blok, 1998; Tajfel \& Turner, 1986; Zografou \& Pipyrou, 2011). For instance, during an informal conversation about dance with a Greek friend, she described the dancing of an Albanian (who now lives in Greece) during his birthday party. She said: "He put the music on and he started to throw his arms around and he was jumping all over the place. I wouldn't call this dancing ... our dances are graceful ... these ones are unstructured and chaotic" (personal communication, May 2010). This comment presents Albanian dances as unstructured in contrast to those of Greece, even though some Greek dances such as zeimbekiko are purely improvisational.

Thus, national dances can act as a means of definition and demarcation between Greece and neighbouring countries such as Albania, Bulgaria, Turkey and the Former Yugoslav Republic of Macedonia (FYROM). But this process of exaggerating the minor differences can also occur within Greece itself. In certain regions where there are ethnic minorities such as Turkish, Muslim or Slavic peoples, dances that are virtually the same are not considered to be 'Greek' when performed by these minorities. In some cases, in particular in Greek Macedonia (a region in northern Greece which borders with FYROM), where the dances of the Slavic minority are similar if not the same as the Greek ones, the minorities themselves also deliberately accentuate the differences in order to mark a distinct identity, separate from the Greek 'other' (Manos, 2003). This situation is perpetuated by the fact that the Greek state does not officially recognise them as ethnic minorities (Triandafyllidou \& Paraskevopoulou, 2002), and views them suspiciously or as potential tools in neighbouring states' irredentist programmes. The state has therefore pursued strategies to "incorporate" them into the existing "national body" (Cowan \& Brown, 2000, p. 11). Particularly in previous eras of dictatorship, as in the case of Metaxas (193640), the state has attempted their forcible assimilation by compelling them to prove themselves as Greek (Manos, 2003). Even today, the minorities are often harassed by police during their village festivals in which Slavic Macedonian folk 
songs and dances are performed (Danforth, 2010). So, these ethnic minorities see their identity as precarious and under threat and seek to preserve their culture in the face of that threat.

Manos (2003) gives an example of the exaggeration of minor differences through the example of a dance event in the district of Florina in northern Greece (Macedonia) where the locals celebrate their annual panigyri, the religious feast of the Prophet Elias. While all the village participates in the church service, the dance event in the evening is celebrated separately: one for the Greeks, which is also attended by the Greek local authorities and the media, and one for the Slav minority. The dances performed at each event are identical and the only difference between them is that the dances are announced in Greek at the 'Greek' event, and in Dopia (the local Slav language) at the 'Slav Macedonian' event, and the same songs are sung in the respective languages. For instance, Kori Eleni and Leno Memo are the same dances but the former is announced and sung in Greek while the latter in Slavic (Manos, 2003). In this way, folk dance contributes to perpetuating the division of the population into two groups.

\section{Dance and crisis}

Although the definition of one group's identity through contrast with others may help to create and preserve that identity, as Billig (1995) shows, it provides a framework which may lead to conflict between the groups in times of crisis. In those cases people seek the familiarity and security of their group identity against the 'other'. Such a crisis may occur because of manipulation by elites and media, or may arise from fear, economic insecurity or competition for resources, for example. In these instances, the identity that has been created through everyday activities, including dance, becomes the primary focus. As Anca Giurchescu (1999) puts it, "Folk [dance] has always been employed in politics to symbolize the nation and to rally people's consciousness" (p. 43). Under these circumstances, people who have danced in everyday life may consciously reflect on how their dance is 'Greek'. Years of active participation in dance has resulted in the embodiment of the Greek identity but reflecting on the dance performance, the Greekness surfaces to conscious levels. The unconsciously absorbed dancing identity becomes consciously reflective. In everyday life, people may usually see themselves as simply dancing, but in these circumstances, they see themselves as 'Greek dancing' or dancing Greekness. This occurred 
during the new 'Macedonian Question', vi a dispute between Greece and the Former Yugoslav Republic of Macedonia over the name 'Macedonia', which emerged in 1991 after the breakup of Yugoslavia, in which cultural elements including Greek dance were highly implicated to showcase the unique Greek heritage.

\section{CONCLUSION}

In conclusion, I have demonstrated that the practice of folk dance in everyday social events in contemporary Greece constitutes a form of banal nationalism. I have argued that national identity is constructed, learned and reinforced by the habitus-the everyday norm-and illustrated that the masses actively participate in the construction, reproduction and maintenance of that identity during dance events. Recalling my personal experiences as a Greek and drawing on accounts by my interviewees, I have shown that the mundane practice of folk dance acts as a positive affirmation of national identity and creates a strong sense of Greekness. It also leads to conceptions of a cultural and genealogical continuation of the national community and cultivates ideas of a distinct and exclusive national identity in relation to the 'other'.

Further, I have addressed the role of folk dance within the national majority in order to understand why, for example, Greek people feel so strongly about dance and how this sentiment shapes ideas of inclusivity and exclusivity. As a researcher, I entered the field with certain dispositions and, as previously mentioned, understood that my would be driven by a self-reflexive process that denounced any objectivity or total detachment from my culture. I knew that Greek people, myself included, value the social interaction of the dance events and appreciate the corporeality of dancing. I was also aware that the Greeks pride themselves on their unique dance heritage and use it as a symbol of their identity. However, I could not ignore the fact that this sense of pride has almost narcissistic qualities that prevents Greeks from acknowledging that other cultures have equally unique dances. Furthermore, I could not comprehend how a nation that prides itself on hospitality and an inclusive dancing culture uses dance to project their chauvinistic attitudes. This is alarming, especially under the current fragile socio-political and economic climate in Greece (and Southern Europe more widely). Such instability can make people protective/defensive of their cultural identity and lead to formation of exclusive communities with strong national(istic) sentiments. 
Nevertheless, this knowledge can be used to address the hegemonic connotations and prevent the oppression and harassment of ethnic minorities. In other words, can dance challenge ethnocentric attitudes and actually materialise the concept of unity in diversity (Giurchescu, 2001)? The fact that dance is celebrated by Greeks as part of their everyday life should be a promising basis for reinforcing cultural understanding and acceptance of difference and encouraging people to acknowledge that other groups also enjoy dance in the same way. As Shapiro (2008) argues, “A multicultural approach goes against what some regard as our natural human tendency to reject people and cultures that are different from our own", but "helping people to understand, accept, value cultural differences between groups" could be the "ultimate goal of reaping the benefits of diversity" (p. 256). So, a possible strategy to challenge notions of exclusivity could be the incorporation of ethnic minorities' dance repertoires in the educational system to enhance knowledge and understanding of other cultures within the national territory and to stimulate cultural empathy and respect. This is particularly important as Greece becomes more multicultural with immigration from neighbouring countries and from further afield.

\section{REFERENCES}

Allenby-Jaffé, M. (2006). National dance. Ramsbury, UK: Crowood Press.

Anderson, B. (2006). Imagined communities (2nd ed.). London: Verso.

Barboussi, V., \& Vidali, A. (2009). Towards an innovative model of teaching Greek traditional dances. Journal of Dance and Somatic Practices, 1(2),155-168.

Billig, M. (1995). Banal nationalism. London: Sage.

Blok, A. (1998). The narcissism of minor differences. European Journal of Social Theory, 1(1), 33-56.

Callos, C. (2012). The transformative nature of Greek dancing: A qualitative inquiry of adolescent experience (PhD dissertation). Fielding Graduate University, Santa Barbara, CA.

Cowan, J. K. (1990). Dance and the body politic in Northern Greece. Princeton, NJ: Princeton University Press.

Cowan, J. K., \& Brown, K. S. (2000). Introduction: Macedonian Inflections. In J. K. Cowan (Ed.), Macedonia: The politics of identity and difference (pp. 1-27). London: Pluto Press.

Danforth, L. M. (1995). The Macedonian conflict: Ethnic nationalism in a transnational world. Princeton, NJ: Princeton University Press.

Danforth, L. M. (2010, March, 19). The Macedonian minority of Northern Greece. Retrieved October 28, 2012, from: http://www.culturalsurvival.org/publications/cultural-survivalquarterly/greece/macedonian-minority-northern-greece.

Devettere, R. J. (2002). Introduction to virtue ethics: Insights of the ancient Greeks. Washington, D.C.: Georgetown University Press.

Dimaras, C. T. (1972). A history of modern Greek literature. New York, NY: State University of New York Press. 
Doulias, E., Kosmidou, E., Paulogiannis, O., \& Patsiaouras, A. (2005). Examination of participation motives in folk dance groups. Inquiries in Sport and Physical Education, 3(2), 107-112.

Esparza, D. (2010). National identity and the other: Imagining the EU from the Czech Lands. Nationalities Papers, 38(3), 413-436.

Foley, D .E. (2002). Critical ethnography: The reflexive turn. Qualitative Studies in Education, 15(5), 469-490.

Giurchescu, A. (1999). Past and present in field research: A critical history of personal experience. In T. Buckland (Ed.), Dance in the field: Theory, methods, and issues in dance ethnography (pp. 41-54). New York, NY: St. Martin's Press.

Giurchescu, A. (2001). The power of dance and its social and political uses. Yearbook for Traditional Music, 33(1), 109-121.

Glauser, C. (2005). Comparative research about dance and society from the 1930 s to the present in the villages of the Voïo region, in Northern Greece. In E. I. Dunin, A. Wharton, \& L. Felföldi (Eds.), Dance and society: Dancer as a cultural performer (pp. 99-106). Hungary: Acamemiai Kiadó.

Hanna, J. L. (1979). Toward a cross-cultural conceptualisation of dance and some correlate considerations. In J. A. R. Blacking \& J. Kealiinohomoku (Eds.), The performing arts: Music and dance (pp. 17-45). The Hague, Netherlands: Muton Publishers.

Hamilakis, Y. (2003). "Learn history!": Antiquity, national narrative, and history in Greek educational textbooks. In K. S. Brown \& Y. Hamilakis (Eds.), The usable past: Greek metahistories (pp. 39-67). Lanham, MD: Lexington Books.

Herzfeld, M. (1982). Ours once more: Folklore, ideology, and the making of modern Greece. Austin, TX: University of Texas Press.

Hoerburger, F. (1968). Once again: On the concept of "Folk Dance". Journal of the International Folk Music Council, 20, 30-32.

Holst-Warhaft, G. (1998). Rebetica: The double-descended deep songs of Greece. In W. Washabaugh (Ed.), The passion of music and dance: Body, gender and sexuality (pp. 111-126). Oxford, UK: Berg.

Janmaat, J. G. (2006). Popular conceptions of nationhood in old and new European member states: Partial support for the ethnic-civic framework. Ethnic and Racial Studies, 29(1), 50-78.

Karras, A. (2012). Greek dance: An ancient link-A living heritage. Retrieved August 10, 2012, from: http://www.helleniccomserve.com/greek_dance.html.

Kealiinohomoku, J. (1972). Folk dance. In R. M. Dorson (Ed.), Folklore and folklife: An introduction (pp. 381-404). Chicago, IL: University of Chicago Press.

Loutzaki, I. (2001). Folk dance in political rhythms. Yearbook for Traditional Music, $33(1), 127-137$.

Madison, S. (2005). Critical ethnography, method, ethics, and performance. Thousand Oaks, CA: Sage.

Madison, S. (2012). Critical ethnography: Method, ethics and performance (2nd ed.). Thousand Oaks, CA: Sage.

Manos, I. (2002). Visualising culture-Demonstrating identity: Dance performance and identity politics in a border region in Northern Greece (PhD dissertation). University of Hamburg, Hamburg, Germany.

Manos, I. (2003). "To dance or not to dance": Dancing dilemmas in a border region in Northern Greece. Focaal: European Journal of Anthropology, 41, 21-32.

Mascarenhas-Keyes, S. (1987). The native anthropologist: Constrains and strategies in research. In A. Jackson (Ed.), Anthropology at home (pp. 180-195). London, England: Tavistock.

Mavrogordatos, G. T. (2003). Orthodoxy and nationalism in the Greek case. West European Politics, 26(1), 117-136.

Mavrovouniotis, F. H., Argiriadou, E. A., \& Papaioannou, C. S. (2010). Greek traditional dances and quality of old people's life. Journal of Bodywork and Movement Therapies, 14(3), 209-218.

Okely, J. (1992). Anthropology and autobiography: Participatory experience and embodied knowledge. In J. Okely \& H. Callaway (Eds.), Anthropology and autobiography (pp. 1-28). London, England: Routledge. 
Panopoulou, K. (2008). The Panegyri and the formation of Vlach cultural identity. Dance Chronicle, 31(3), 436-504.

Papakostas, C., Prantsidis, I., \& Polatou, E. (2006). Traditional dance in Drama region (Northern Greece): Ethnographic data and rhythmical and movement analysis. Inquiries in Sport and Physical Education, 4(3), 430-441.

Patsidou, L., \& Mavromati, A. (2004). Greek dancing through the centuries: The history and evolution of Greek dance. Retrieved March 10, 2010, from http://www.annasebart.com/culture/dancehistory/charact/index.html.

Raftis, A. (1987). The world of Greek dance. Athens, Greece: Finedawn.

Rakočević, S. (2005). Serbian folk dances today: The problem of authenticity and vitality. In E. I. Dunin, A. Wharton, \& L. Felföldi (Eds.), Dance and society: Dancer as a cultural performer (pp. 129-136). Budapest, Hungary: Acamemiai Kiadó.

Riak, P. (2011). Celebrations during a traditional wedding of the Island of Rhodes. Dance Chronicle, 34(3), 388-421.

Shapiro, S. B. (2008). Dance in a world of change: A vision for global aesthetics and universal ethics. In S. B. Shapiro (Ed.), Dance in a world of change: Reflections on globalization and cultural difference (pp. 253-276). Champaign, IL: Human Kinetics.

Shay, A. (1999). Parallel traditions: State folk dance ensembles and folk dance in "The field". Dance Research Journal, 31(1), 29-56.

Shay, A. (2008). Balkan dance: Essays on characteristics, performance and teaching. Jefferson, NC: MCFarland and Company.

Sklar, D. (2001). Five premises for a culturally sensitive approach to dance. In A. Dills \& A. Cooper Albright (Eds.), Moving history/dancing culture: A dance history reader (pp. 30-32). Middletown, CT: Wesleyan University Press.

Strathern, M. (1987). The limits of auto-anthropology. In A. Jackson (Ed.), Anthropology at home (pp. 16-37). London, England: Tavistock.

Tajfel, H., \& Turner, J. (1986). The social identity theory of intergroup behavior. In S. Worchel \& W. G. Austin (Eds.), Psychology of intergroup relations (pp. 7-24). Chicago, IL: Nelson-Hall.

Triandafyllidou, A. (2005). When, what and how is the Nation?: Lessons from Greece. In A. Ichijo \& G. Uzelac (Eds.), When is the nation? Towards an understanding of theories of nationalism (pp. 177-195). Abingdon, UK: Routledge.

Triandfyllidou, A., \& Paraskevopoulou, A. (2002). When is the Greek nation? The role of enemies and minorities. Geopolitics, 7(2), 75-98.

Tvrtko, Z. (1996). Surviving through the dance: Sung round dance as the expression of defiance and Croatian pride. Traditional Music in Community Life, 20(4), 1-5.

Tzanelli, R. (2006). "Not my Flag!" Citizenship and nationhood in the margins of Europe (Greece, October 2000/2003). Ethnic and Racial Studies, 29(1), 27-49.

Van de Berghe, P. L. (2005). Ethnies and nations: Genealogy indeed. In A. Ichijo \& G. Uzelac (Eds.), When is the Nation?: Towards an understanding of theories of nationalism (pp. 113-118). Abingdon, UK: Routledge.

Ward, A. (1997). Dancing around meaning (and the meaning around dance). In H. Thomas (Ed.), Dance in the city (pp. 3-20). Basingstoke, UK: Macmillan Press.

Ward, C., Fox, S., Wilson, J., Stuart, J., \& Kus, L. (2010). Contextual influences on acculturation process: The roles of family, community and society. Psychological Studies, 55(1), 26-34.

Wingrave, H., \& Harrold, R. (1984). Aspects of folk dance in Europe. London: Dance Books.

Wodak, R., de Cellia, R., Reisigl, M., \& Liebhart, K. (2009). The discursive construction of national identity (2nd ed.). Edinburgh, Scotland: Edinburgh University Press.

Yiakoumaki, V. (2006). Ethnic Turks and "Muslims", and the performance of multiculturalism: The case of the Drómeno of Thrace. South European Society and Politics, 11(1), 145-161.

Zikos, I. (1993). O Neoellinikos Horos ipo tous Orous tis Sineheias kai Diarkeias [NeoHellenic Dance under the Conditions of Continuity and Perpetuity]. In A. Raftis (Ed.), I Didaskalia tou Horou [The Teaching of Dance]. Athens, Greece: International Organisation of Folk Art-Greek Section. 
Zografou, M. (2007). The politics of dance: The incorporation of the Pontic refugees in modern Greek culture through the manipulation of dancing practices in a Northern Greek village. Journal of Mediterranean Studies, 17(1), 1-21.

Zografou, M., \& Pipyrou, S. (2011). Dance and difference: Toward an individualisation of the Pontian self. Dance Chronicle, Special Issue: Preserving Dance in the Diaspora, $34(3), 422-446$.

\footnotetext{
${ }^{i}$ Enculturation is a process of socialisation by which the individual acquires knowledge of the values, beliefs and norms that constitute his/her society during development. This concept is different to acculturation, which is used to describe the changes and influences that take place when two groups of a different background come into contact; for example, when immigrants come into contact with the dominant cultural group (Ward, Fox, Wilson, Stuart, \& Kus, 2010).

ii The 'other' is "an essential element in the construction of an identity", by which the 'self' is defined in relation to the 'other' according to differences (Esparza, 2010, p. 415). According to Madison (2005), the 'other' has tended to be viewed as a marginalised, objectified, degenerated and outcast identity. However, in critical ethnography the 'other' has been re-conceptualised as a subject in its own right, while it is the ethnographer's responsibility to "cross the boundaries into the territories of Otherness in order to engage with the Other in their own terms" (Madison, 2005, p. 97). Hence, it is not about defining self in relation to other but an ethical responsibility to serve justice for the other.

iii During the fieldwork I kept journal notes, especially of two dance events (a baptism and my niece's wedding) at which I was a guest. The group interviews were recorded and translated by me.

iv George Mavrogordatos (2003) argues that the identification of the Greek nation with Orthodoxy was "irresistible from the very beginning" (p. 128).

${ }^{v}$ One example is provided by Rodanthi Tzanelli (2006), who gives an account of how an Albanian child was not allowed to carry the Greek flag at the national day celebration in a town in northern Greece.

vi For further details on the New Macedonian Question conflict see Danforth (1995) and Triandafyllidou (2005).
} 